\begin{tabular}{ll}
\hline \hline MINING AND METALLURGY INSTITUTE BOR & ISSN: 2334-8836 \\
& UDK: 622 \\
\hline \hline
\end{tabular}

\title{
DEFINING THE SIZE CLASS AS THE QUALITY PARAMETER OF ZEOLITE ASSORTMENT OF PRODUCTS ${ }^{* * * *}$
}

\begin{abstract}
Quality requirements for the product assortments, obtained from a large number of non-metallic mineral raw materials, are defined, and above all, they have the defined particle size. Are the quality requirements for zeolite assortments defined? Searching for the answer to this question, an internet research was done. The web pages of the most significant producers of materials based on natural zeolite were studied as well as the papers of a large number of prominent researchers whose experiments are focused on the natural zeolite. This paper presents the findings primarily with the aspect of particle size as the quality parameter of zeolite assortments. Based on this analysis, it is considered that it should define the quality requirements of zeolite assortments, especially the particle size for each product. In fact, it is important to know the particle size in mineral processing in order to choose less expensive procedure for obtaining the finall product.

Keywords: natural zeolite, zeolite assortment, quality requirement, mineral processing, particle size of zeolite assortment
\end{abstract}

\section{INTRODUCTION}

In order to investigate the possibility of use the non-metallic mineral raw material, i.e. to determine whether one or more useful products can be obtained from some non-metallic raw material, it is necessary to know the required quality of that product, i.e. which quality of that product is needed by the end users. This subject is most often regulated by standards for each material, obtained from non-metallic mineral raw material which has users and application. So, for example, there are standards for calcium carbonate raw materials which define the quality requirements for products used in a range of industries.
Quality requirements relate to the physical, chemical, mineralogic and other properties of given material. They define minimum or maximum values of specific parameters and the allowed discrepancies. The basic and initial parameter in this respect is the particle size, respectively size class, respectively range of products. Particle size is important from the aspect of its application since not all material sizes can be used for any application. There are similar standards for products obtained from quartz raw materials, clays, feldspars, phosphates, etc. There are standards of particular states, and there are some

\footnotetext{
* Institute for Technology of Nuclear and Other Mineral Raw Materials, Franchet d Esperey 86, 11000 Belgrade, Serbia, z.sekulic@itnms.ac.rs

** University of Belgrade, Faculty of Mining and Geology, Djušina 7, 11000 Belgrade, Serbia

*** This paper is the result of investigations within the Projects 034013 and 172018, funded by the Ministry of Education and Science of the Republic of Serbia from 2011-2014.
} 
standards for the EU countries. What is the state of affairs in this respect when it comes to one of the most significant nonmetallic mineral raw materials-zeolite? It was searched for the answer to this question on web pages the most significant manufacturers of natural zeolite products, as well as by means the investigation of papers published by a large number of prominent researchers of natural zeolite. Only the certain aspect of the particle size range of products was studied. The observations and recommendations are presented in this paper.

\section{OVERVIEW OF ZEOLITE PRODUCTION ASSORTMENTS}

When zeolite production is in question, Robert L. Wirth presents the production and mine reserves [1]. Natural zeolite production was the highest in 2011 in China and it amounted to nearly 2,000,000 tons (including pozzolanic applications). Apart from China, the biggest producers are the United States, Japan, Jordan, South Korea, Slovakia and Turkey. All others produced around 5,500 tons in 2011. The world total (rounded) in 2011 was 2,800,000 T.
Speaking about the processes of obtaining the zeolite products for further application, it is interesting that F. A. Mumpton 1977[2] wrote about application and obtaining the products based on natural zeolite. This author, at the end of this consideration wrote: "For many ion exchange applications, the desired size range is $20 \times 50$ mesh (850 to 300/am) which has been found to optimize the contact time and hydraulic characteristics of packed columns".

The internet research provided data on companies in the business of manufacturing products from natural zeolite. In this paper, the most interesting data are present according to the evaluation from websites of the nine companies worldwide. These data relate to the assortments (i.e. particle size) and product use in the market, and details can be found on websites of these companies, which are present in Tables 1 and 2.The present data in Table 1 show a wide range of natural zeolite products. Those assortments (size classes) are different for the same application. Assortments are in the range from $-32+16$ to less than 20 micrometers.

Table 1 Testing the production of zeolite assortments obtained from natural zeolite and their application

\begin{tabular}{|c|c|c|c|c|}
\hline \multirow[b]{2}{*}{$\begin{array}{c}\text { Application of natural } \\
\text { zeolite }\end{array}$} & \multicolumn{4}{|c|}{ Company / website / and assortment, mm } \\
\hline & $\begin{array}{c}\text { USA } \\
\text { Bear River zeolite } \\
\text { co., inc [3] }\end{array}$ & $\begin{array}{c}\text { USA } \\
\text { St. Cloud Mi- } \\
\text { ning Co. }[4]\end{array}$ & $\begin{array}{c}\text { USA } \\
\text { Steelhead } \\
\text { Specialty } \\
\text { Minerals[5] }\end{array}$ & $\begin{array}{l}\text { USA } \\
\text { ZEO, } \\
\text { Inc. [6] }\end{array}$ \\
\hline 1) Water Treatment & & \multirow[b]{2}{*}{$\begin{array}{c}\text { Powders } \\
-0.044 \\
-0.149 \\
-0.42\end{array}$} & & \\
\hline Aquaculture & $\begin{array}{r}-12.7+4.76 \\
-4.76+2.38 \\
-4.76+1.41 \\
-1.41+0.4 \\
\end{array}$ & & & \\
\hline Wastewater treatment & $-0.4+0$ & \multirow{5}{*}{$\begin{array}{c}\text { Sands } \\
-0.4+0.177 \\
-1.41+0.4\end{array}$} & $-4.76+2.38$ & \\
\hline Drinking water treatment & $1.41+0.4$ & & $-1.41+0.4$ & \\
\hline Pool filters & $1.41+0.4$ & & & $\begin{array}{r}\text { SVZ } 0.65 \\
\text { Ko } 1.85 \\
\end{array}$ \\
\hline Flocculation & & & & \\
\hline For fish ponds & & & & \\
\hline
\end{tabular}




\begin{tabular}{|c|c|c|c|}
\hline $\begin{array}{l}\text { Modified or combined } \\
\text { zeolites }\end{array}$ & & \multirow{16}{*}{$\begin{array}{l}\text { Granules } \\
-4.76+3.36 \\
-3.36+2.38 \\
-3.36+1.41 \\
-.2 .38+1.41\end{array}$} & \\
\hline $\begin{array}{l}\text { 2) Animal and Feed and } \\
\text { Agricultural }\end{array}$ & & & \\
\hline Complete feed mixture & $-1.4+0.4$ & & $-0.5+0$ \\
\hline Animal feeds mixture & & & $\begin{array}{l}\text { Ultra, } \\
-45 \mu \mathrm{m}\end{array}$ \\
\hline Soil & & & \\
\hline Soil remediation & $\begin{array}{r}-1.41+0.4 \\
-0,4+0,25 \\
-0,4+0\end{array}$ & & $-1.4+0.25$ \\
\hline For lawns & $\begin{array}{r}-2.38+1.41 \\
-1.41+0.4 \\
-0.595+0.25\end{array}$ & & \\
\hline For pellets & $-0.4+0$ & & \\
\hline $\begin{array}{l}\text { For artificial fertilizers } \\
\text { and substrate }\end{array}$ & & & \\
\hline For golf courses & & & \\
\hline 3) Air Treatment & & & \\
\hline Air Filtration & $-9.51+6.35$ & & \\
\hline Removal of impurities & & & \\
\hline 4) Industry & & & \\
\hline $\begin{array}{l}\text { Concrete and pozzolanic } \\
\text { for cement }\end{array}$ & $-0.045+0$ & & \\
\hline $\begin{array}{l}\text { Fillers in paper, cardboard, } \\
\text { plastic, rubber, adhesives, } \\
\text { asphalt }\end{array}$ & $\begin{array}{r}-0.4+0 \\
-0.15+0\end{array}$ & & \\
\hline
\end{tabular}

Table 2 Review the production of zeolite assortments obtained from natural zeoilite and their application

\begin{tabular}{|c|c|c|c|c|c|}
\hline \multirow[b]{2}{*}{$\begin{array}{l}\text { Application of natu- } \\
\text { ral zeolite }\end{array}$} & \multicolumn{5}{|c|}{ Company / website / and assortment, mm } \\
\hline & $\begin{array}{c}\text { Australia } \\
\text { Zeolite } \\
\text { Australia } \\
\text { Pty Ltd } \\
\text { [7] }\end{array}$ & $\begin{array}{c}\text { South } \\
\text { Africa } \\
\text { Pratley } \\
\text { (Pty) } \\
\text { Ltd[8] }\end{array}$ & $\begin{array}{c}\text { Turkey Rota } \\
\text { Madencilik } \\
\text { [9] }\end{array}$ & $\begin{array}{l}\text { Slovakia } \\
\text { ZEOCEM } \\
\text {, a. s. [10] }\end{array}$ & $\begin{array}{c}\text { Spain } \\
\text { ZeoCat } \\
\text { S.L.U[11] }\end{array}$ \\
\hline 1) Water Treatment & & & \multirow{5}{*}{$\begin{array}{l}\text { Grain Sizes } \\
\text { We can produce } \\
\text { any grain size } \\
\text { according to } \\
\text { your require- } \\
\text { ments. Below } \\
\text { there is a list of } \\
\text { grain sizes in our } \\
\text { standard produc- } \\
\text { tion line: }\end{array}$} & & \\
\hline Aquaculture & & & & & $\begin{array}{r}-32+16 \\
-16+8 \\
-8+4 \\
-2.5+2 \\
-2+1 \\
-1+0.5 \\
\end{array}$ \\
\hline Wastewater treatment & & & & & \\
\hline $\begin{array}{l}\text { Drinking water } \\
\text { treatment }\end{array}$ & & $-0.84+0.25$ & & & \\
\hline Pool filters & & & & & \\
\hline
\end{tabular}




\begin{tabular}{|c|c|c|c|c|c|}
\hline Flocculation & $-0.075+0$ & & \multirow{17}{*}{$\begin{array}{l}-20 \text { microns, } \\
-50 \text { micron, } \\
-75 \text { microns, } \\
-0.1 \\
-0.225 \\
-0.425 \\
-1.18+0.7 \\
-1.6+0.7 \\
-2.5+1 \\
-5+2.5 \\
--9+5 \\
-16+9\end{array}$} & & \multirow[b]{4}{*}{$\begin{array}{r}-8+4 \\
-4+2.5 \\
-2.5+1.2 \\
-1.2+0.5 \\
\end{array}$} \\
\hline For fish ponds & $-2+0.5$ & & & & \\
\hline \multicolumn{3}{|l|}{$\begin{array}{l}\text { Modified or combined } \\
\text { zeolites }\end{array}$} & & & \\
\hline $\begin{array}{l}\text { 2) Animal and Feed } \\
\text { and Agrocultural }\end{array}$ & & & & & \\
\hline $\begin{array}{l}\text { Complete feed } \\
\text { mixture }\end{array}$ & $\begin{array}{r}-0.075+0 \\
-0.5+0\end{array}$ & & & $\begin{array}{r}-1+0 \\
-1+0.5 \\
-1+0.2 ; \\
-0.5+0.2 ; \\
-0.2+0\end{array}$ & \\
\hline Soil remediation & $\begin{array}{r}-1.6+0.5 \\
-2+0.5\end{array}$ & & & & \\
\hline For pellets & $\begin{array}{r}-0.075+0 \\
-0.5+0 \\
\end{array}$ & & & & \\
\hline $\begin{array}{l}\text { For artificial fertilizers } \\
\text { and substrate }\end{array}$ & $\begin{array}{r}-0.075+0 \\
-0.5+0\end{array}$ & $\begin{array}{r}-4+2 \\
-4+0.25\end{array}$ & & $\begin{array}{r}-1+0.3 \text {; } \\
-8+4 ; \\
-5+2.5 \\
-5+1 ; \\
-2.5+1\end{array}$ & \\
\hline For golf courses & & $-0.84+0.25$ & & & \\
\hline 3) Air Treatment & & & & & \\
\hline Air Filtration & & & & & \\
\hline Remove impurities & & & & & \\
\hline 4) Industry & & & & $\begin{array}{r}-8+5 \\
-4+2,5 \\
-2.5+1 \\
-1+0.5 \\
-0.5+0.2\end{array}$ & \\
\hline $\begin{array}{l}\text { Concrete and } \\
\text { pozzolanic for cement }\end{array}$ & & & & & \\
\hline 5) Other Products & & & & & \\
\hline Environment & & & & $\begin{array}{r}-8+5 \\
-4+2.5 \\
-2.5+1 \\
-1+0.5 \\
-0.5+0.2 \\
\end{array}$ & $-5+2$ \\
\hline Wide range & & & & & $-0.7+0$ \\
\hline
\end{tabular}

\section{REVIEW OF RESEARCH PAPERS FROM THE ASPECT OF NATURAL ZEOLITE}

For the purpose of easier research, this paper presents the review of conditional classification according to theapplicability of natural zeolite. Three references were

used for this list of application the zeolite products: website[1,12] and [10].

- Physical, chemical and mineralogical characterization 
- Natural zeolite - water treatment

- Environmental application of natural zeolite

- Natural zeolite in agriculture and animal nutrition

- Natural zeolite in cement and ceramic bodies

- Biomedical and biotechnological applications of natural zeolite

- Ion exchange of natural zeolites/surface modified natural zeolites

\subsection{Characterization of natural zeolite}

Zeolite characterization is usually performed on samples taken in the beginning of preparation and processing, after that they are ground in laboratory into powder, for example $<0.063 \mathrm{~mm}$ [13-17]. However, O. Korkuna, et al. [18] in the paper Structural and Physico-chemical properties of Natural Zeolites:Cclinoptilolite and Mordenite, chose the fractions of clinoptilolite with the particle size ds $=0.355-0.5 \mathrm{~mm}$ and mordenite of $\mathrm{ds}=0.2-0.315 \mathrm{~mm}$ for investigation.

\subsection{Natural zeolites for water treatment}

Researchers dealing with water treatment use the following natural zeolite size classes, obtained from the raw material: $-2+0.5 \mathrm{~mm} ;-1.5+0 \mathrm{~mm} ;-0.2+0.15 \mathrm{~mm}$; $-0.16+0.04 \mathrm{~mm} ;-0.075+0 \mathrm{~mm}$ and -0.02 mm. For example Denes Kallo[19] used particle size in the range of $40-160 \mu \mathrm{m}$, whereas Filippidis[20] tested the sample < $0.5 \mathrm{~mm}$.

\subsection{Environmental application of natural zeolite}

Investigations are carried out on natural zeolite classes $-2.4+1.4 \mathrm{~mm} ;-1.4+0.4 \mathrm{~mm}$; $-0.4+0 \mathrm{~mm}$. Zeocern company from Slovakia offers the following products of this kind: $-8+5 \mathrm{~mm}$; $-4+2.5 \mathrm{~mm}$; $-2.5+1 \mathrm{~mm}$; $-1+0.5 \mathrm{~mm} ;-0.5+0.2 \mathrm{~mm}$. The authors Englert and Rubio [21] homogenized and sieved the sample below $149 \mu \mathrm{m}$ (100 Mesh
Tylerk) before characterization and experimentation. Saltali et al. [22] published the Removal of Ammonium Ion from Aqueous Solution by Natural Turkish (Ylldizeli) Zeolite for Environmental Quality. They used the commercial sample of natural Turkish zeolite (Yildizeli town of Sivas) as an adsorbent in this study, supplied from Rota A.S, Mining Company, Istanbul, Turkey. The natural zeolite samples were crushed in a mortar and sieved using 200-mesh (0.075 $\mathrm{mm}$ ) sieve. Godelitsas et al. [23] in the report of investigation of uranium sorption from aqueous solutions used the HEUtype of zeolite crystals (particle-size $<20$ $\mu \mathrm{m})$ by means of a batch-type method. Godelitsasand associates dealt with the adsorption of $\mathrm{Ni}, \mathrm{Cu}$ and $\mathrm{Co}-\mathrm{Heu}$ using zeolite grains 20-90 microns. Misaelides [24] dealt with the application of surfactant-modified zeolites to the environmental remediation and use of natural zeolites in the permeable reactive barriers. Leyva-Ramos [25] in his paper "Removal of Ammonium from Aqueous Solution by Ion Exchange on Natural and Modified Chabazite" performed the investigations on samples of zeolitic rocks from the mineral deposit in the state of Sonora, Mexico. The zeolite samples were ground and sieved to the average particle diameter of $0.18 \mathrm{~mm}(-70+100$ US mesh). Results of investigations from this field were also published by Ming and Alen [26], Colella [27], Capelletti [28].

\subsection{Natural zeolites in agriculture and animal nutrition}

Researchers use $-0.5+0 \mathrm{~mm}$ or $0.3+0$ $\mathrm{mm}$ zeolite classes. The company "Australia zeolite" (Table 2) offers the following products: $-0.075+0 \mathrm{~mm} ;-0.5+0 \mathrm{~mm} ;-1.6+0.5$ $\mathrm{mm} ;-2+0.5 \mathrm{~mm}$. Zeocem Slovakia offers complete feed mixture for feed additives (Table 2): $-1+0 \mathrm{~mm} ;-1+0.5 \mathrm{~mm} ;-1+0.2$ $\mathrm{mm} ;-0.5+0.2 \mathrm{~mm} ;-0.2+0 \mathrm{~mm}$.

Mumpton and Fishman in the paper „The Application of Natural Zeolites in Animal Science and Aquaculture", say: "For 
many ionexchange applications the desired size range is $20 \times 50$ mesh ( 850 to $300 / \mathrm{am}$ ) which has been found to optimize contact time and hydraulic characteristics of packed columns. Filippidis [29] presents the results of investigations on zeolite from Greece. The Hellenic Natural Zeolite (HENAZE) sample was used from a vertical profile. The sample was ground $<0.5 \mathrm{~mm}$ and homogenized.

\subsection{Natural zeolites in cement and ceramic bodies}

The following sizes are mentioned in the papers: $-0.88+0.5 \mathrm{~mm}$ and production of pellets in sizes 23 to $27 \mathrm{~mm}$ or 11 to $13 \mathrm{~mm}$. Zeocem company offers the following product classes for this purpose: $-1+0 \mathrm{~mm}$; $-1+0.5 \mathrm{~mm} ;-1+0.2 \mathrm{~mm},-0.2+0 \mathrm{~mm}$. Bear river zeolite co., inc offers class $-0.4+0 \mathrm{~mm}$ and $-0.15+0 \mathrm{~mm}$.

Mertens et al. [30] published in the study: "The grain size of all the samples after wet milling was determined in an aqueous suspension by laser diffraction using the Malvern Mastersizer S Long Bed with a 300RF optical lens for grain sizes between $880 \mu \mathrm{m}$ and 0:05". Dondi et al. [31] used eighteen zeolite bearing rocks from Sardinia; campaigns and Tuscany were taken into account, along with low densities (0.5-0.7 GCM-3) and fair technical characteristics (mass and strength loose particles). De Gennaro [32] for light aggregates used two different sizes of particles: one set was $23-27 \mathrm{~mm}$, and other 11-13 mm. These sets are obtained starting from 3.36 and $0.31 \mathrm{~cm}^{3}$ pellets, respectively. Lilkov [33,34] and Chipera and Bish [35] did not mention the size of the material they had used.

\subsection{Biomedical and biotechnological applications of natural zeolites}

Colella [36] wrote a critical reconsideration of biomedicaland veterinary applications of natural zeolites. The starting sample was not cited. Polat [37] in his doctoral thesis states that the sample was used in 75-150 micron sized particles. Orha et al. [38], state that the study used azeolite mineral from the Romanian region Mirsid with a grain diameter for experiments between 315-500 microns.

\subsection{Ion exchange of natural zeolites / surface modified natural zeolite}

Researchers have mostly experimented in this field on the basis of natural zeolite. The results of their investigations can be applied in several fields since the ion exchange occurs in any field of usage the natural zeolite.. However, the researchers are mainly focused on investigations the results that can be used in application of zeolite products for animal feed or water purification. Researchers use a range of size classes for this purpose: powder, $-5+2 \mathrm{~mm}$; $-2+0,5 \mathrm{~mm} ;-2+0 \mathrm{~mm} ;-2.4+1.4 \mathrm{~mm}$; $-1.4+0.4 \mathrm{~mm} ;-0.4+0 \mathrm{~mm} ;-0.1+0 \mathrm{~mm}$; $-0.8+0.6 \mathrm{~mm} ;-0.5+0 \mathrm{~mm} ;-0.5+0.315 \mathrm{~mm}$; $-0.15+0.075 \mathrm{~mm} ; \quad-0.090+0.063 \mathrm{~mm}$; $-0.5+0.1 \mathrm{~mm} ;-0.1+0.04 \mathrm{~mm} ;-0.63+0 \mathrm{~mm}$; $0.2+0 \mathrm{~mm} ;-0.043+0 \mathrm{~mm} ;-0.1+0.063 \mathrm{~mm}$.

Tarasevic et al. [39], in the Microcalorimetric Study of the Interaction between Water and Cation-Substituted Clinoptilolites, used for experiments $0.25-0.5 \mathrm{~mm}$ fractions, too, when determining the $Q 0$ values of cation-substituted forms of clinoptilolite. Tomazović et al. [40] used for experiments the natural zeolite with sized particles of 0.090-0.063 mm. Trgo and Perić [41], used for experiments the natural zeolite particle size of $\mathbf{0 . 1 - 0 . 5} \mathbf{~ m m}$ from the Croatian deposit Donje Jesenje. Misaelides et al. [42], used for investigations the homogenized materials, pulverized samples of zeolie ferous rocks from Georgia and Greece with grain size $<2 \mathrm{~mm}$ or -10 mesh. Mendoza-Barron et al. [43], used the modified natural zeolite from the deposit located in San Luis Potosi, Mexico. The sample was ground and sieved to the average particle size of $0.42 \mathrm{~mm}(-20+30$ US mesh). 


\section{OBSERVATIONS AND CONCLUSIONS}

Ćurković et al. [44], published a paper entitled Kinetics and Thermodynamics Study of Copper Ions Removal by Natural Clinoptilolite. Natural clinoptilolite zeolite from Donje Jasinje was used in three size classes: $-0.5 \mathrm{~mm},-2+0.5 \mathrm{~mm}$ i $-5+2 \mathrm{~mm}$. Trgo et al. [45], used the natural zeolite sample with particle size of 0.04-0.10 mm. Simpson and Bowman [46], used zeolite in their investigations which was the natural clinoptiloliterich tuff from the St. Cloud mine near Winston, New Mexico. The zeolite was crushed and sieved to 14-40 mesh size (1.4 - to 0.4 $\mathrm{mm}$ diameter). Faghihian and Bowman [47], used in their investigations two different size fractions, $0.4-1.4 \mathrm{~mm}$ and $1.4-2.4 \mathrm{~mm}$. Sullivan et al., [48], prepared the SMZ from a clinoptilolite zeolite from New Mexico. The external cation exchange capacity of zeolite, determined by Ming and Dixon method (1987), was found to be approximately 70 to $90 \mathrm{mmolc} / \mathrm{kg}$. Bowman [49] used the natural clinoptilolite-rich zeolitic tuff New Mexico with particle size <0.4 $\mathrm{mm}, 1.4-0.4 \mathrm{~mm}$, or $2.4-1.4 \mathrm{~mm}$. Tomašević-Canović et al. [50]: the starting material used in the experiments was raw zeolitic tuff sieved to yield particles $<100 \mu \mathrm{m}$. Vujaković et al. [51], Daković et al. [52]: The starting material used in the experiments was raw zeolitic tuff sieved to yield particles $<0.063 \mathrm{~mm}$. Stanić et al. [53] used for experiments the raw zeolitic tuff zeolite from the Bala Mare deposit in Romania, and the sample was prepared under $0.2 \mathrm{~mm}$ in size. Krajišnik et al. [54]: The raw zeolitic tuff was sieved to yield particles below $43 \mu \mathrm{m}$. Cerjan Stefanović et al. [55] proved that the highest absorption of metallic cations on fraction of grain size of 0.1 to $0.063 \mathrm{~mm}$, so that the reasons why they had chosen this fraction. Šiljeg et.al. [56] were chosen the fractions of grain size of 0.1 to $0.5 \mathrm{~mm}$ for experimental work.
Based on the presented review, it can be concluded that there are no standardized physical, chemical or mineralogical parameters of quality for zeolite assortments for any field of application, unlike in the case of some other non-metallic mineral raw materials. There are regulations for pozzolanic additives of cement (which are applied on zeolite, too) used for those purposes (European Standard EN 197 and Italian Standard UNI 7549...). There are regulations defining the allowed impurities in the animal feed, so zeolite must conform with those regulations, too, but the minimum content of zeolite mineral, maximum harmful impurities, minimum CEC or the size of the product are not defined. Companies that process the natural zeolite in commercial products, as proof of the quality of these products, provide the tests for various application areas. Tests show that zeolite acts better than alternative materials. Researchers use a variety of particle size for the same purposes. For example, some researchers use classes $-0.5+0 \mathrm{~mm}$ for water treatment and animal feed, while others use $0.063+0$ $\mathrm{mm}$ etc. Frederick Mumpton, at the end of 1999, discussed the role of scientists in the study of mineral zeolite, and said that the role of scientists is multidisciplinary. The joint effort of scientists is essential to understand, for example, the zeolite functions in the digestive system of animals. He added that for further, besides all, the aspect of mineral processing should be present. It was observed in this research that: the particle size of zeolite assortments is not standardized for any application. But, in mineral processing, it is essential to know: whether the zeolite assortments were obtained by crushing and sieving process or it is necessary to carry out the other complex mineral processing operations. Due to this, probably, in the future, the manufacturers 
of zeolitic product ranges and researchers, who work with natural zeolite, together with users have to define the quality requirements, and especially the particle size as the quality parameter of zeolite assortments.

\section{REFERENCES}

[1] http://minerals.usgs.gov/minerals/ pubs/commodity/zeolites/

[2] F.A. Mumpton, P.H. Fishman, The Application of Natural Zeolites in Animal Science and Aquaculture.J. ANIM. SCI., 45(1977), p.1188

[3] www.bearriverzeolite.com

[4] http://www.stcloudmining.com

[5] www.steelheadspecialtyminerals.com

[6] www.zeoinc.com

[7] www.zeolite.com.au

[8] http://www.pratley.com

[9] http://www.rotamadencilik.com.tr/

[10] http://www.zeocem.com/

[11] http://www.zeocat.es

[12] F. A. Mumpton, Colloquium Paper, La rocamagica: Uses of natural zeolites in agriculture and industry. Proc. Natl. Acad. Sci. USA, 96(1999), p.3463

[13] O. Díaz Rizo, E.F. Herrera Peraza, Multi-elemental characterization of Cuban natural zeolites. J. Radioanal. Nucl. Chem. 212(1997), No 1-2, p.255

[14] T. Armbruster, Clinoptilotite-heulandite: applications and basic research, Zeolites and Mesoporous Materials at the dawn of the $21^{\text {st }}$ century. Proceedings of the 13 International Zeolite Conference, Montpellier, France. Studies in Surface Science and Catalysis, 135(2001), p. 13

[15] L. S. Gadekar, S. S. Katkar, K. N. Vidhate, B. R. Arbad, M. K. Lande, Modification, characterization and catalytic potency of modified natural zeolite for Knoevenagel condensation reaction. Bulletin of the Catalysis Society of India, 7(2008), p. 76

[16] G. V.Tsitsishvili, N. S. Skhirtladze, T. G. Andronikashvili, V. G. Tsitsishvili, A. V. Dolidze, Natural zeolites of Georgia: Occurrences, properties, and application, Studies in Surface Science and Catalysis, 125(1999), p. 715

[17] D. L. Bish,and J.W. Carey, Thermal Behavior of Natural Zeolites, Rev. Mineral. Geochem., 45(2011), p. 403

[18] O. Korkuna, R. Leboda, J. Skubiszewska-Ziba, T. Vrublevs'ka, J. Gun'ko, V. M. Ryczkowski, Structural and physicochemical properties of natural zeolites: clinoptilolite and mordenite, Microporous Mesoporous Mater. 87(2006), p. 243

[19] D. Kalló, Wastewater purification in Hungary using natural zeolites, In: Natural Zeolites '93: Occurrence, Properties, Use. Ming D W, Mumpton F A, editors. Brockport, NY: Int. Comm. Nat. Zeolites, (1995), p. 341

[20] A. A. Filippidis, Environmental, industrial and agricultural applications of Hellenic Natural Zeolite, Hellenic Journal of Geosciences, 45(2010), p. 91

[21] A. H. Englert, J. Rubio, Characterization and environmental application of a Chilean natural zeolite, Int. J. Miner. Process, 75(2005), No 1-2, p. 21

[22] K. Saltali, A. Sari, M. Aydin, Removal of ammonium ion from aqueous solution by natural Turkish (Y1ldızeli) zeolite for environmental quality, J. Hazard. Mater, 141(2007) No.1, p. 258

[23] A. Godelitsas, P. Misaelides, A. Filippidis, D. Charistos, I. Anousis, Uranium sorption from aqueous solutions on sodium-form of HEU-type zeolite crystals, J. Radioanal. Nucl. Chem. 208(1996), No. 2, p. 393

[24] P. Misaelides, Application of natural zeolites in environmental remediation: 
A short review, Microporous Mesoporous Mater. 44(2011), No.1-3, p. 15

[25] R. Leyva-Ramos, J.E. MonsivaisRocha, A. Aragon-Piña, M.S. BerberMendoza, R.M. Guerrero-Coronado, P. Alonso-Davila, J. Mendoza-Barron, Removal of ammonium from aqueous solution by ion exchange on natural and modified chabazite, J. Environ. Manage., 91(2010), p. 2662

[26] D. W. Ming and E. R. Allen, Use of natural zeolites in agronomy, horticulture, and environmental soil remediation, Rev. Mineral. Geochem., 45(2001), p. 618

[27] C. Colella, Natural zeolites and environment, Stud. Surf. Sci. Catal., 2007, Chapter 27, p. 999

[28] P. Cappelletti, G. Rapisardo, B. de Gennaro, A. Colella, A. Langella, S.F. Graziano, D.L. Bish, M. de Gennaro, Immobilization of $\mathrm{Cs}$ and $\mathrm{Sr}$ in aluminosilicate matrices derived from natural zeolites, J. Nucl. Mater., 414(2011), p. 451

[29] A. Filippidis, G. Papastregios, N. Apostolidis, S. Filippidis, I. Paragios, C. Sikalidis, Purification of urban wastewaters by Hellenic natural zeolite, Bulletin of the Geological Society of Greece, 43(2010), No.5, p. 2597

[30] G. Mertens, R. Snellings, K. Van Balen, B. Bicer-Simsir, P. Verlooy, J. Elsen, Pozzolanic reactions of common natural zeolites with lime and parameters affecting their reactivity, Cem. Concr. Res., 39(2009), No.3, p. 233

[31] M. Doldi, P. Cappelletti, G.Cerri, M. Gennaro, R. Gennaro, A. Langella, Zeolitic tuffs as raw materials for lightweight aggregates., Key Eng. Mater., 2004, No. 264-268, p. 1431

[32] R. de' Gennaro, P. Cappelletti, G. Cerri, M. de' Gennaro, M. Doldi, A. Langella, Zeolitic tuffs as raw materials for lightweight aggregates, Appl. Clay Sci., 25(2004), No.1-2, p. 71
[33] V. Lilkov, O. Petrov, V. Petkova, N. Petrova, Y. Tzvetanova, Study of the pozzolanic activity and hydration products of cement pastes with addition of natural zeolites, Clay Miner., 46(2011), p. 241

[34] V. Lilkov, O. Petrov, Y. Tzvetanova, Rheological, porosimetric, and SEM studies of cements with additions of natural zeolites, Clay Miner., 46(2011) p. 225

[35] S. J. Chipera, D. L. Bish, Rehydration kinetics of a natural analcime, Eur. J. Mineral., 22(2010), p. 787

[36] C. Colella, A critical reconsideration of biomedical and veterinary applications of natural zeolites, Clay Miner., 46(2011), No. 2, p. 295

[37] Z. Polat, Integrated approach to whey utilization through natural zeolite adsorption/desorption and fermentation, [Dissertation], The Graduate School of Engineering and Sciences, Izmir, 2009, p. 209

[38] C. Orha, F. Manea, A. Pop, G. Burtica, I. F. Todea, Obtaining and Characterization of Zeolitic Materials with Antibacterial Properties, Rev. Chim., 59(2008), No. 2, p. 173

[39] Yu.I. Tarasevich, I. G. Polyakova, V. E. Polyakov, Microcalorimetric Study of the Interaction between Water and Cation-Substituted Clinoptilolites, Colloid J., 65(2003), No. 4, p. 493

[40] B. Tomazović, T. Ćeranić, G. Sijarić, The properties of the $\mathrm{NH}$,-clinoptilolite, Zeolites, 16(1996) No.4, p. 301

[41] M. Trgo, J. Perić, Interaction of the zeolitic tuff with Zn-containing simulated pollutant solutions, J. Colloid Interface Sci., 260(2003), No. 1, p. 166

[42] P. Misaelides, V.A. Nikashina, A. Godelitsas, P.A. Gembitskii, E.M. Kats, Sorption of As(V)-anions from aqueous solutions by organo-modified natural zeolitic materials, J. Radioanal. Nucl. Chem. 227(1998), No. 1-2, p. 183 
[43] J. Mendoza-Barrón, A. Jacobo-Azuara, R. Leyva-Ramos, M.S. BerberMendoza, R.M. Guerrero-Coronado, L. Fuentes - Rubio, J.M. MartínezRosales, Adsorption of arsenic (V) from a water solution onto a surfactantmodified zeolite, Adsorption, 17(2011), No. 3, p. 489

[44] L. Ćurković, M. Trgo, M. Rožić, N. V. Medvidović, Kinetics and thermodynamics study of copper ions removal by natural clinoptilolite, Indian J. Chem. Technol., 18(2011), No. 2, p. 137

[45] M. Trgo, J. Perić, N.V. Medvidović, A comparative study of ion exchange kinetics in zinc/lead-modified zeoliteclinoptilolite systems, J. Hazard. Mater., 136(2006), No. 3, p.938

[46] J. A. Simpson, R. S. Bowman, Nonequilibrium sorption and transport of volatile petroleum hydrocarbons in surfactant-modified zeolite, J. Contam. Hydrol., 108(2009), No. 1-2, p. 1

[47] H. Faghihian, R.S. Bowman, Adsorption of chromate by clinoptilolite exchanged with various metal cations, Water Res., 39(2005), No. 6, p. 1099

[48] E. J. Sullivan, R. S. Bowman, I. A. Legiec, Sorption of Arsenic from SoilWashing Leachate by SurfactantModified Zeolite, J. Environ. Qual., 32(2003), No. 6, p. 2387

[49]. R. S. Bowman, Applications of surfactant-modified zeolites to environmental remediation, Microporous Mesoporous Mater., 61(2003), No. 1-3, p. 43

[50] M. Tomašević-Čanović, A. Daković, G. Rottinghaus, S. Matijašević, M. Duričić, Surfactant modified zeolites new efficient adsorbents for mycotoxins, Microporous Mesoporous Mater.,61(2003), No. 1-3, p. 173
[51] A. Vujaković, M. Tomaševíć-Čanović, A. Daković, V. Dondur, The adsorption of sulphate, hydrogenchromate and dihydrogenphosphate anions on surfactant-modified clinoptilolite, Appl. Clay Sci., 17(2000), No. 5-6, p. 265

[52] A. Daković, M. Tomašević-Čanović, G. Rottinghaus, V. Dondur, Z. Mašić, Adsorption of ochratoxin A on octadecyldimethyl benzyl ammonium exchanged-clinoptilolite-heulandite tuff, Colloids Surf. B., 30(2003), No. 1-2, p. 157

[53] T. Stanić, A. Daković, A. Živanović, M. Tomašević-Čanović, V. Dondur, S. Milićević, Adsorption of Arsenic (V) by Iron (III)-Modified Natural Zeolitic Tuf, Environ. Chem. Lett., (2009), p. 161

[54] D. Krajišnik, A. Daković, M. Milojević, A. Malenović, M. Kragović, D.B. Bogdanović, V. Dondur, J. Milić, Properties of Diclofenac Sodium Sorption onto Natural Zeolite Modified with Cetylpyridinium Chloride, Colloids Surf. B , 83(2011), p. 165

[55] Š. Cerjan Stefanović, N. Logar Zabukovec, K. Margeta, N. Novak Tušar, I. Arčon, K. Maver, J. Kovač, J. Kaučič, Structural Investigation of $\mathrm{Zn}^{2+}$ Sorption on Clinoptilolite Tuff from the Vranjska Banja Deposit in Serbia, Microporous Mesoporous Mater., 105(2007), p. 251

[56] M. Šiljeg, S.C. Stefanović, M. Mazaj, N. Tušar, I. Arčon, J. Kovač, K. Margeta, N.Z. Logar, Structure investigation of $\mathrm{As}(\mathrm{III})$ - and $\mathrm{As}(\mathrm{V})$ species bound to Fe-modified clinoptilolite tuffs, Microporous Mesoporous Mater. 118(2009), No. 1-3, p. 408 


\begin{tabular}{ll}
\hline \hline INSTITUT ZA RUDARSTVO I METALURGIJU BOR & ISSN: \\
& UDK: 622:669 \\
\hline \hline
\end{tabular}

\section{DEFINISANJE KRUPNOĆE KAO PARAMETRA KVALITETA ZEOLITSKIH ASORTIMANA PROIZVODA ${ }^{* * *}$}

Izvod

Zahtevi za kvalitet asortimana proizvoda koji se dobijaju iz velikog broja nemetaličnih mineralnih sirovina su definisani, a iznad svega, imaju definisanu veličinu čestica. Da li su zahtevi za kvalitet asortimana na bazi zeolita definisani? Tragajući za odgovorom na ovo pitanje izvršili smo internet istraživanje. Pregledali smo internet stranice najznačajnijih proizvođača materijala na bazi prirodnog zeolita, kao i radove velikog broja istaknutih istraživača čiji su eksperimenti fokusirani na prirodni zeolit. Ovaj rad predstavlja naše nalaze, pre svega sa aspekta veličine čestica kao parametra kvaliteta zeolitskih asortimana proizvoda. Na osnovu ove analize, smatramo da bi trebalo da se definišu zahtevi kvaliteta, posebno veličina čestica za svaki proizvod na bazi zeolita. U stvari, u pripremi mineralnih sirovina je važno da znate veličinu čestica, kako bi izabrali jeftiniji postupak za dobijanje konačnog proizvoda.

Ključne reči: prirodni zeolite, zeolitski asortiman, uslovi kvaliteta, postupci pripreme, veličina čestice zeolitskih asortimana

\section{UVOD}

U cilju ispitivanja mogućnosti upotrebe nemetalnih mineralnih sirovina, odnosno utvrđivanja da li se na bazi neke nemetaličnih mineralnih sirovina može dobiti jedan ili više korisnih proizvoda, potrebno je znati traženi kvalitet tog proizvoda, odnosno koji kvalitet tog proizvoda je potreban za krajnjeg korisnika. Ovo pitanje je najčešće regulisano standardima za svaki materijal dobijeno dnemetalnih mineralnih sirovina koja ima korisnika i primenu. Tako, na primer, za kalcijum-karbonat postoje standardi koji definišu zahteve za kvalitet proizvoda koji se koriste u različitim industrijama. Zahtevi kvaliteta se odnose na fizičke, hemijske, mineraloške i druge osobine datog materijala. Oni definišu minimalne i maksimalne vrednosti određenih parametara i dozvoljena odstupanja. Osnovni i početni parametar $\mathrm{u}$ tom smislu jeste veličina čestica, odnosno klasa krupnoće, odnosno asortiman proizvoda. Veličina čestica je važna sa aspekta njegove primene, jer ne mogu se koristiti sve veličine čestica za bilo koju aplikaciju. Postoje slični standardi za proizvode dobijene iz kvarcnih sirovina,

\footnotetext{
* Institut za tehnologiju nuklearnih i drugih mineralnih sirovina, Franše d'Eperea 86, 11000 Beograd, Srbija, e-mail: z.sekulic@itnms.ac.rs

*** Univerzitet u Beogradu, Rudarsko geološki fakultet, Đušina 7, 11000 Beograd, Srbija

*** Ovaj rad je rezultat istraživanja u okviru projekta 034013 „Osvajanje tehnoloških postupaka dobijanja ekoloških materijala na bazi nemetaličnih mineralnih sirovina“ $i 172018$ „Porozni materijali na bazi oksida u zaštiti životne sredine od genotoksičnih supstanci”, koje finansira Ministarstvo prosvete, nauke i tehnološkog razvoja Republike Srbije od 2011-2014.
} 
glina, feldspata, fosfata, itd. Postoje standardi pojedinih država, a postoje neki standardi za zemlje EU. Kakvo je stanje u tom pogledu, kada je u pitanju jedna od najznačajnijih nemetaličnih mineralnih sirovina - zeolit? Mi smo tražili odgovor na ovo pitanje na veb stranicama najznačajnijih proizvođača prirodnog zeolita proizvoda, kao i putem istraživanja objavljenih radova od strane velikog broja istaknutih istraživača prirodnog zeolita. Proučavali smo samo određeni aspekt opseg veličine čestica proizvoda. Naša zapažanja i preporuke su prikazani u ovom radu.

\section{PREGLED PROIZVODNJE ZEOLITSKIH ASORTIMANA}

Kada je u pitanju proizvodnja zeolita, Robert L. Virta predstavlja proizvodnju i rudne rezerve [1]. Proizvodnja prirodnih zeolita je najveća u Kini u 2011. godini i iznosila je skoro 2.000.000 tona (uključuje pucolanske aplikacije). Pored Kine, najveći proizvođači su SAD, Japan, Jordan, Južna Koreja, Turska i Slovačka. Svi ostali su proizveli oko 5.500 tona u 2011. godini. Svet je ukupno (zaokruženo) u 2011. godini proizveo 2.800.000 t.

F. A. Mumpton je još 1977 [2] pisao o primeni i dobijanju proizvoda na bazi priordnog zeolita. Naša istraživanja su na bazi podataka sa Interneta o kompanijama koje proizvode proizvoda od prirodnih zeolita. U ovom radu predstavićemo najinteresantnije podatke prema našim procenama iz sajtovima devet kompanija širom sveta. Ovi podaci odnose se na asortimane (odnosno čestica po krupnoći) i primenu proizvoda na tržištu, a detalje možete pronaći na sajtovima ovih kompanija, koje su prikazane u tabeli 1. i 2. .Podaci prikazani u tabeli 1 pokazuju širok spektar proizvoda na bazi zeolita. Ovi asortimani se razlikuju za istu aplikaciju. Asortimani su u rasponu od -32 do +16 i manje od 20 mikrometara.

Tabela 1. Istraživanje proizvodnje zeolitskih asortimana dobijeni od prirodnog zeolita $i$ njihove primene

\begin{tabular}{|c|c|c|c|c|}
\hline \multirow[b]{2}{*}{ Primena prirodnog zeolita } & \multicolumn{4}{|c|}{ Kompanija / websajt / i asoriman, mm } \\
\hline & $\begin{array}{c}\text { USA } \\
\text { Bear river } \\
\text { zeolite co., } \\
\text { Inc [3] }\end{array}$ & $\begin{array}{c}\text { USA } \\
\text { St. Cloud } \\
\text { Mining Co. } \\
{[4]} \\
\end{array}$ & $\begin{array}{c}\text { USA } \\
\text { Steelhead } \\
\text { Specialty } \\
\text { Minerals [5] } \\
\end{array}$ & $\begin{array}{c}\text { USA } \\
\text { ZEO, Inc. } \\
{[6]}\end{array}$ \\
\hline \multicolumn{2}{|l|}{ 1) Tretman vode } & \multirow{8}{*}{$\begin{array}{c}\text { Prah } \\
-0.044 \\
-0.149 \\
-0.42 \\
\\
\text { Pesak } \\
-0.4+0.177 \\
-1.41+0.4\end{array}$} & & \\
\hline Akva kultura & $\begin{array}{r}-12.7+4.76 \\
-4.76+2.38 \\
-4.76+1.41 \\
-1.41+0.4 \\
\end{array}$ & & & \\
\hline Tretman otpadne vode & $-0.4+0$ & & $-4.76+2.38$ & \\
\hline Tretman vode za piće & $-1.41+0.4$ & & $-1.41+0.4$ & \\
\hline Filteri za bazene & $-1.41+0.4$ & & & $\begin{array}{r}\text { SVZ } 0.65 \\
\text { Ko } 1.85\end{array}$ \\
\hline Flokulacija & & & & \\
\hline Za ribnjake & & & & \\
\hline $\begin{array}{l}\text { Modifikovani ili } \\
\text { kombinovani zeolit }\end{array}$ & & & & \\
\hline
\end{tabular}




\begin{tabular}{|c|c|c|c|}
\hline $\begin{array}{l}\text { 2) Hrana za životinje i } \\
\text { agrokultura }\end{array}$ & & \multirow{14}{*}{$\begin{array}{c}\text { Granulat } \\
-4.76+3.36 \\
-3.36+2.38 \\
-3.36+1.41 \\
-2.38+1.41\end{array}$} & \\
\hline Kompletna mešavina & $-1.4+0.4$ & & $-0.5+0$ \\
\hline Mešavina stočne hrane & & & $\begin{array}{r}\text { Ultra } \\
-45 \mathrm{mM}\end{array}$ \\
\hline Zemljišste & & & \\
\hline Remediacija & $\begin{array}{r}-1.41+0.4 \\
-0,4+0,25 \\
-0,4+0\end{array}$ & & $-1.4+0.25$ \\
\hline Za travnjake & $\begin{array}{r}-2.38+1.41 \\
-1.41+0.4 \\
-0.595+0.25 \\
\end{array}$ & & \\
\hline Za pelete & $-0.4+0$ & & \\
\hline Za golf terene & & & \\
\hline 3) Tretman vazduha & & & \\
\hline Filtracija & $-9.51+6.35$ & & \\
\hline Uklanjanje nečistoća & & & \\
\hline 4) Industrija & & & \\
\hline Beton i pucolan za cement & $-0.045+0$ & & \\
\hline $\begin{array}{l}\text { Fileri papira, kartona, } \\
\text { plastike, gume, lepila, } \\
\text { asfalt }\end{array}$ & $\begin{array}{r}-0.4+0 \\
-0.15+0\end{array}$ & & \\
\hline
\end{tabular}

Tabela 2. Pregled istraživanja proizvodnje zeolitskih asortimana dobijenih od prirodnog zeolita i njihova primena

\begin{tabular}{|c|c|c|c|c|c|}
\hline \multirow[b]{2}{*}{$\begin{array}{c}\text { Primena prirodnog } \\
\text { zeolita }\end{array}$} & \multicolumn{5}{|c|}{ Kompanija / websajt / i asoriman, mm } \\
\hline & $\begin{array}{c}\text { Australia } \\
\text { Zeolite } \\
\text { Australia } \\
\text { Pty Ltd [7] }\end{array}$ & $\begin{array}{c}\text { South } \\
\text { Africa } \\
\text { Pratley } \\
\text { (Pty) Ltd } \\
{[8]} \\
\end{array}$ & $\begin{array}{c}\text { Turkey Rota } \\
\text { Madencilik [9] }\end{array}$ & $\begin{array}{c}\text { Slovakia } \\
\text { ZEOCEM, a. } \\
\text { s. }[10]\end{array}$ & $\begin{array}{c}\text { Spain } \\
\text { ZeoCat } \\
\text { S.L.U [11] }\end{array}$ \\
\hline \multicolumn{6}{|l|}{ 1) Tretman vode } \\
\hline Akvakultura & & & \multirow{2}{*}{$\begin{array}{l}\text { Mi možemo da } \\
\text { proizvodimo bilo } \\
\text { koju veličinu zrna } \\
\text { u skladu sa vašim } \\
\text { zahtevima. Ispod je } \\
\text { spisak od veličine } \\
\text { zrna u našoj stan- } \\
\text { dardnoj proizvo- } \\
\text { dnoj liniji: }\end{array}$} & & $\begin{array}{r}-32+16 \\
-16+8 \\
-8+4 \\
-2.5+2 \\
-2+1 \\
-1+0.5\end{array}$ \\
\hline $\begin{array}{l}\text { Tretman otpadne } \\
\text { vode }\end{array}$ & & & & & \\
\hline $\begin{array}{l}\text { Tretman vode za } \\
\text { piće }\end{array}$ & & $-0.84+0.25$ & \multirow{3}{*}{$\begin{array}{l}\text {-20 mikrometara, } \\
-50 \text { mikrometara } \\
-75 \text { mikrometara } \\
-0.1\end{array}$} & & \\
\hline Filteri za bazene & & & & & \\
\hline Flokulacija & $-0.075+0$ & & & & \\
\hline
\end{tabular}




\begin{tabular}{|c|c|c|c|c|c|}
\hline Za ribnjake & $-2+0.5$ & & \multirow{16}{*}{$\begin{array}{l}-0.225 \\
-0.425 \\
-1.18+0.7 \\
-1.6+0.7 \\
-2.5+1 \\
-5+2.5 \\
--9+5 \\
-16+9\end{array}$} & & \multirow[b]{3}{*}{$\begin{array}{r}-8+4 ; \\
-4+2.5 ; \\
-2.5+1.2 ; \\
-1.2+0.5\end{array}$} \\
\hline $\begin{array}{l}\text { Modifikovani ili } \\
\text { kombinovani } \\
\text { zeolit }\end{array}$ & & & & & \\
\hline $\begin{array}{l}\text { 2) Hrana za } \\
\text { životinje i } \\
\text { agrokultura }\end{array}$ & & & & & \\
\hline $\begin{array}{l}\text { Kompletna } \\
\text { mešavina }\end{array}$ & $\begin{array}{r}-0.075+0 \\
-0.5+0\end{array}$ & & & $\begin{array}{r}-1+0 ;-1+0.5 \\
-1+0.2 \\
-0.5+0.2 \\
-0.2+0 \\
\end{array}$ & \\
\hline $\begin{array}{l}\text { Mešavina stočne } \\
\text { hrane }\end{array}$ & $\begin{array}{r}-1.6+0.5 \\
-2+0.5 \\
\end{array}$ & & & & \\
\hline Za pelete & $\begin{array}{r}-0.075+0 \\
-0.5+0 \\
\end{array}$ & & & & \\
\hline $\begin{array}{l}\text { Za veštačka } \\
\text { đubriva i podloge }\end{array}$ & $\begin{array}{r}-0.075+0 \\
-0.5+0\end{array}$ & $\begin{array}{r}-4+2 \\
-4+0.25\end{array}$ & & $\begin{array}{r}-1+0.3 ;-8+4 \\
-5+2.5 ;-5+1 \\
-2.5+1\end{array}$ & \\
\hline Za golf terene & & $-0.84+0.25$ & & & \\
\hline 3) Tretman vazduha & & & & & \\
\hline Filtracija & & & & & \\
\hline $\begin{array}{l}\text { Uklanjanje } \\
\text { nečistoća }\end{array}$ & & & & & \\
\hline 4) Industrija & & & & $\begin{array}{r}-8+5 ;-4+2,5 \\
-2.5+1 \\
-1+0.5 \\
-0.5+0.2\end{array}$ & \\
\hline $\begin{array}{l}\text { Beton i } \\
\text { pucolanski } \\
\text { dodatak cement }\end{array}$ & & & & & \\
\hline 5) Drugi proizvodi & & & & & \\
\hline Zaštita & & & & $\begin{array}{r}-8+5 ;-4+2.5 \\
-2.5+1 \\
-1+0.5 \\
-0.5+0.2\end{array}$ & $-5+2$ \\
\hline Širok opseg & & & & & $-0.7+0$ \\
\hline
\end{tabular}

\section{PREGLED ISTRAŽIVAČKIH \\ RADOVA SA ASPEKTA \\ PRIRODNOG ZEOLITA}

Radi lakšeg istraživanja, ovaj rad predstavlja pregled prema uslovnoj podeli prirodnog zeolita na osnovu primenjivost.

Koristili smo tri reference za ovaj spisak primene zeolitskih proizvoda [1,12] i [10]:
- fizička, hemijska i mineraloška karakterizacija,

- prirodni zeolit - tretman vode,

- primena prirodnog zeolita u životnoj sredini, 
- prirodni zeolit u poljoprivredi i ishrane životinja,

- prirodni zeolit $\mathrm{u}$ industriji cementa i keramike,

- biomedicinske i biotehnološke primene prirodnog zeolita,

- jonske izmena prirodnih zeolita/površinski modifikovani prirodni zeoliti.

\subsection{Karakterizacija prirodnog zeolita}

Karakterizacija zeolita se obično vrši na uzorcima uzetim $u$ početku pripreme $\mathrm{i}$ obrade, nakon čega se u laboratoriji usitnjavaju u prah, na primer $<0,063 \mathrm{~mm}$ [13-17]. Međutim, O. Korkuna i drugi [18] u radu Strukturne i fizičko-hemijske osobine prirodnih zeolita: klinoptilolita $i$ mordenita, za istraživanje su izabrali frakcije klinoptilolita veličine čestica $\mathrm{ds}=0.355-0.5 \mathrm{~mm}$ mordenite $\mathrm{ds}=0.2$ $0.315 \mathrm{~mm}$.

\subsection{Prirodni zeolit za tretman vode}

Istraživači koji se bave tretmanom vode koriste sledeće klase krupnoće : $-2+0,5 \mathrm{~mm}$; $-1.5-0.2+0 \mathrm{~mm} ;+0,15 \mathrm{~mm} ;-0.16+0,04$ $\mathrm{mm} ;-0.075+0 \mathrm{~mm}$ i $-0.02 \mathrm{~mm}$. Na primer Denes Kallo [19] koristi veličinu čestica u opsegu 40-160 mikrometara, dok Filippidis [20 ] ispituje uzorak koji je $<0.5 \mathrm{~mm}$.

\subsection{Primena prirodnog zeolita u životnoj sredini}

Istraživanja se obavljaju na prirodnm zeolitu klase - $2.4+1,4 \mathrm{~mm}$; - $1.4+0,4 \mathrm{~mm}$, $0.4+0 \mathrm{~mm}$. Zeocem, Slovačka kompanija, nudi sledeće proizvode ove vrste: $-8+5 \mathrm{~mm}$; $-4+2.5 \mathrm{~mm} ;-2.5 \mathrm{~mm} ;-1+1+0.5 \mathrm{~mm} ;-0.5$ $+0,2 \mathrm{~mm}$. Autori Englert i Rubio [21] homogenizuju i prosejavaju uzorak ispod 149 mikrometara (100 meša) pre karakterizacije i eksperimentisanja. Saltali i saradnici [22] su koristili komercijalni uzorak prirodnog zeolita kao adsorbent, koji se dobija iz rudarske kompanije. Prirodni uzorci su usitnjeni i prosejavani na 0,075 mm. Godelitsas i dr. [23] u Izveštaju o istraživanjima sorpcije uranijuma iz vodenih rastvora koriste Heu - tip zeolita (čestica veličine $<20 \mathrm{mkm}$ ). Godelitsas i saradnici za adsorpciju Ni, Cu i pomoću Heu zeolita koriste krupnoću 20-90 mikrometara. Misaelides [24] se bavi primenom površinski - modifikovanih zeolita u sanaciji životne sredine. Leiva-Ramos [25] u svom radu "Uklanjanja amonijaka iz vodenog rastvora od jonske izmene na prirodni i modifikovani chabazite" vrši istraživanje na uzorcima zeolitnih stena od mineralnih ležišta u državi Sonora u Meksiku. Uzorci su na terenu prosejavanja na čestice prečnika od 0.18 $\mathrm{mm}$. Rezultate istraživanja iz ove oblasti su takođe objavili Ming i Alen [26], Colella [27], Capelletti [28].

\subsection{Prirodnih zeolita u poljoprivredi i ishrane životinja}

Istraživači koriste klase zeolita $-0.5+$ 0 mm ili $0,3 \quad+0 \quad \mathrm{~mm}$. Kompanija "Australija zeolit" (Tabela 2) nudi sledeće proizvode: $-0.075+0 \mathrm{~mm} ;-0.5-1.6+0$ $\mathrm{mm} ;+0,5+0,5 \mathrm{~mm} ;-2 \mathrm{~mm}$. Zeocem Slovačka nudi kompletnu smešu za aditiv (Tabela 2): $-1+0 \mathrm{~mm} ;-1+0,5+0,2 \mathrm{~mm}$; $1 \mathrm{~mm} ;+0,2 \mathrm{~mm}$; $-0.5-0.2+0 \mathrm{~mm}$.

Mumpton i Fishman u radu "Primena prirodnih zeolita u stočarstvu i akvakulturi" kažu: "Za mnoge aplikacije jonske izmene željeni opseg veličina je 0.850 do $0.300 \mathrm{~mm}$. Filippidis [29] predstavlja rezultate istraživanja o zeolitu iz Grčke. Koristi se prirodni zeolit (HENAZE) krupnoće < 0,5 mm koji se homogenizuje

\subsection{Prirodni zeolit u industriji cementa i keramike}

U radovima se sledeće veličine pominju: $-0.88+0.5 \mathrm{~mm}$ i proizvodnju peleta $\mathrm{u}$ veličinama od 23 do $27 \mathrm{~mm}$, ili 11 do 13 $\mathrm{mm}$. Zeocem firma nudi sledeće proizvode za ovu svrhu: $-1+0 \mathrm{~mm}$; $-1+0.5 \mathrm{~mm}$; -1 $+0,2 \mathrm{~mm},-0.2+0 \mathrm{~mm}$. Bear River zeolit CO 
Doo nudi klase $-0.4+0 \mathrm{~mm}$ i $-0.15+0 \mathrm{~mm}$ .Mertens i dr. [30] su u Studiji koristili čestice uzoraka, nakon mokrog mlevenja, veličine $0,880 \mathrm{~mm}$ i 0.05 . Dondi i dr. [31] koriste osamnaest zeolitskih ležišta iz Sardinije, kampanije iz Toskane. Uzeti su u obzir uzorci male gustine $\left(0.5-0.7 \mathrm{~g} / \mathrm{cm}^{3}\right)$. De Đenaro [32] za lake agregate koristi dve različite veličine čestica: jedan set je 23-27 $\mathrm{mm}$, i drugi $11-13 \mathrm{~mm}$. Ovi skupovi su dobijeni polazeći od 3,36 do $0,31 \mathrm{~cm}^{3}$ peleta, respektivno. Lilkov [33,34] i Chipera i Bish [35] nisu pominjali veličinu materijala koji su koristili.

\subsection{Biomedicinska i biotehnološka primena prirodnih zeolita}

Colella [36] je kritički preispitivao biomedicinsku i veterinarsku primenu prirodnog zeolita. Polazni uzorak nije bio defnisan. Polat [37] u svojoj doktorskoj tezi navodi koristi uzorak krupnoće 75-150 mikrometar. Orha i dr. [38], je naveo da u studiji koristi mineral zeolit iz oblasti Mirsid prečnika između 315-500 mikrometara.

\subsection{Jonske izmene prirodnih zeolita / površinski modifikovani prirodni zeolit}

Istraživači su u ovoj oblasti uglavnom eksperimentisali na bazi prirodnog zeolita. Rezultati njihovih istraživanja mogu se primeniti u nekoliko oblasti jonske izmene $\mathrm{u}$ kojoj se prirodni zeolit koristi. Međutim, istraživači su uglavnom fokusirani na istraživanja čiji rezultati se mogu koristiti za primenu zeolitskih asortimana za stočnu hranu, odnosno prečišćavanje vode. Istraživači koriste različite klase krupnoće za ovu namenu: prah, $-5+2 \mathrm{~mm} ;-2+0,5 \mathrm{~mm}$; $-2+0 \mathrm{~mm} ;-2.4+1,4 \mathrm{~mm},-1.4+0,4 \mathrm{~mm},-0.4$ $+0 \mathrm{~mm} ;-0.1+0 \mathrm{~mm} ;-0.8+0,6 \mathrm{~mm},-0.5+$ $0 \mathrm{~mm} ;-0.5+0.315 \mathrm{~mm} ;-0.15+0.075 \mathrm{~mm}$, $0,090+0,063 \mathrm{~mm},-0.5+0,1 \mathrm{~mm},-0.1+0,04$ $\mathrm{mm}$; - +0 0,63 mm; $-0.2+0 \mathrm{~mm} ;-0.043+$ $0 \mathrm{~mm} ;-0.1+0.063 \mathrm{~mm}$.
Tarasevič i dr. [39], u svom radu za eksperimente koristi frakciju 0.25-0.5 mm, Tomazović i dr. [40] za eksperimente na prirodni zeolitima koriste čestice veličine 0.090-0.063 mm. Trgo i Perić [41] su u svom eksperimentalnom radu koristili priordni zeolit krupnoće 0,1-0,5 mm, izležišta Donje Jesenje u Hrvatskoj. Misaelides i dr. [42], koriste homogenizovan materijal, mleveni uzorak stena iz Gruzije i Grčke granulacije <2 mm ili -10 mesh. MendozaBaron i drugi [43], za istraživanja koriste modifikovani zeolit iz ležišta koje se nalazi u San Luis Potosi, Meksiko. Uzorak je prosejavan na prosečnu veličinu čestica od 0,42 mm (-20 +30 US meša). Ćurković i dr. [44], objavili su rad pod nazivom Istraživanje kinetike $i$ termodinamike uklanjanja jona bakra prirodnim klinoptilolitom. Prirodnog zeolita tipa Donje Jasinje je korišćen u tri veličine klase: $-0.5 \mathrm{~mm}+0,5$ $\mathrm{mm},-2 \mathrm{i}+2-5 \mathrm{~mm}$. Trgo i dr. [45], za istraživanje su koristili prirodni zeolit veličine čestica 0.04-0.10 mm. Simpson i Boumen [46] su koristili klinoptilolit-tuf iz St. Cloud kamenolomu kod Vinstona, Novi Meksiko koji je prirodno bogat. Zeolit je drobljen i prosejavan na 14 - 40 meša (1,4 - 0,4 mm). Faghihian i Boumen [47], u svojim istraživanjima koriste dve različite veličine frakcije: 0.4 - $1.4 \mathrm{~mm}, 1.4$ - $2.4 \mathrm{~mm}$. Sullivan i saradnici [48], pripremaju SMZ od zeolita iz Novog Meksika. Spoljni kapacitet katjonske izmene zeolita je 70 do $90 \mathrm{mmolc} / \mathrm{kg}$. Bowman [49] koristi prirodni klinoptilolitom bogat zeolitni tuf iz Novog Meksika, veličine čestica $<0,4 \mathrm{~mm}, 1.4-0.4 \mathrm{~mm}$, ili 2.4 - $1.4 \mathrm{~mm}$. Tomašević - Čanović i dr. [50]: Polazni materijal koji se koristi u eksperimentima je zeolitni tuf koji se prosejava na veličinu čestica <100 mikrometara. Vujaković i dr. [51], Daković i dr. [52] koriste polazni materijal koji se koristi u eksperimentima sirov zeolitni tuf prosejavan na čestice $<0.063 \mathrm{~mm}$. Stanić i dr. [53] za eksperimente su koristili sirov zeolitni tuf iz Bala Mare ležišta u Rumuniji, a uzorak je bio pripremljen na $-0,2$ mm. Krajišnik i dr. 
[54] koriste sirov zeolitni tuf koji je prosejavan na čestice ispod 43 mikrometara. Cerjan - Stefanović i sar. [55]: Dokazano je da je najveća apsorpcija metalnih katjona na frakciji veličine zrna od 0,1 do $0.063 \mathrm{~mm}$, pa su zato izabrali ovu frakciju. Šiljeg i saradnici [56] su izabrali frakcije veličine zrna od 0,1 do $0,5 \mathrm{~mm}$ za eksperimentalni rad.

\section{ZAPAŽANJA I ZAKLJUČCI}

Na osnovu prikazanog pregleda može se zaključiti da ne postoje standardizovani fizički, hemijski ili mineraloški parametri kvaliteta za zeolitske asortimane za bilo koju oblast primene, za razliku od nekih drugih nemetaličnih mineralnih sirovina. Postoje propisi za pucolanski dodatak cementu (koji se primenjuju na zeolit, takođe) koji se koriste u te svrhe (evropski standard EN 197 i UNI Italijanski standard 7549 ...). Postoje propisi koji definišu dozvoljene nečistoće u hrani za životinje, tako da zeolit mora $u$ skladu sa tim propisima da ispunjava uslove, ali minimalni sadržaj minerala zeolita, najviše štetnih primesa, minimalni kapcitet katjonske izmene ili krupnoća proizvoda nisu definisani. Kompanije koje prerađuju prirodni zeolit u komercijalne proizvode, kao dokaz o kvalitetu ovih proizvoda daju testove za različite oblasti primene. Testovi pokazuju da zeolit deluje bolje od alternativnih materijala. Istraživači koriste različite veličine čestica za iste svrhe. $\mathrm{Na}$ primer, neki istraživači koriste klase $-0.5+0$ $\mathrm{mm}$ za preradu vode i hrane za životinje, dok drugi koriste $0.063+0 \mathrm{~mm}$ i dr. Frederik Mumpton krajem 1999. godini, u studiji iz zeolita, kaže da je uloga naučnika multidisciplinarna. Zajednički napor naučnika je od suštinskog značaja ako želimo da razumemo, na primer, funkcije zeolita u digestivnom traktu životinja. On je dodao da za dalje, pored ostalih, i aspekt pripreme mineralnih sirovina treba da bude zastupljen. U našem istraživanju smo primetili: veličine čestica zeolitski asortimana nije standardizovan za bilo koju primenu. Ali, u pripremi mineralnih sirovina je važno da se zna: da li se asortimani dobijaju drobljenjem i prosejavanjem ili su potrebne druge složene operacije. Zbog toga, verovatno, u budućnosti, proizvođači zeolitnih asortiman i istraživači koji rade sa prirodnim zeolitom, zajedno sa korisnicima treba da definišu zahteve kvaliteta, a pre svega veličinu čestica kao parametar kvaliteta zeolita sortimenata.

\section{LITERATURA}

[1] http://minerals.usgs.gov/minerals /pubs /commodity/zeolites/

[2] F.A. Mumpton, P.H. Fishman, The Application of Natural Zeolites in Animal Science and Aquaculture. J. ANIM. SCI., 45(1977), p.1188

[3] www.bearriverzeolite.com

[4] http://www.stcloudmining.com

[5] www.steelheadspecialtyminerals.com

[6] www.zeoinc.com

[7] www.zeolite.com.au

[8] http://www.pratley.com

[9] http://www.rotamadencilik.com.tr/

[10] http://www.zeocem.com/

[11] http://www.zeocat.es

[12] F.A. Mumpton, Colloquium Paper, La roca magica: Uses of natural zeolites in agriculture and industry. Proc. Natl. Acad. Sci. USA, 96(1999), p.3463

[13] O. Díaz Rizo, E. F. Herrera Peraza, Multi-elemental characterization of Cuban natural zeolites. J. Radioanal. Nucl. Chem. 212(1997), No 1-2, p.255

[14] T. Armbruster, Clinoptilotite-heulandite: applications and basic research, Zeolites and Mesoporous Materials at the dawn of the 21st century. Proceedings of the 13 International Zeolite Conference, Montpellier, France. Studies in Surface Science and Catalysis, 135(2001), p. 13

[15] L. S. Gadekar, S. S. Katkar, K. N. Vidhate, B. R. Arbad, M. K. Lande, Modification, characterization and 
catalytic potency of modified natural zeolite for Knoevenagel condensation reaction. Bulletin of the Catalysis Society of India, 7(2008), p. 76

[16] G. V. Tsitsishvili, N. S. Skhirtladze, T. G. Andronikashvili, V. G. Tsitsishvili, A. V. Dolidze, Natural zeolites of Georgia: Occurrences, properties, and application, Studies in Surface Science and Catalysis, 125(1999), p. 715

[17] D. L. Bish, and J. W. Carey, Thermal Behavior of Natural Zeolites, Rev. Mineral. Geochem., 45(2011), p. 403

[18] O. Korkuna, R.Leboda, J. Skubiszewska-Ziba, T. Vrublevs'ka, J. Gun'ko, V.M. Ryczkowski, Structural and physicochemical properties of natural zeolites: clinoptilolite and mordenite, Microporous Mesoporous Mater. 87(2006), p. 243

[19] D. Kalló, Wastewater purification in Hungary using natural zeolites, In: Natural Zeolites '93: Occurrence, Properties, Use. Ming D W, Mumpton F A, editors. Brockport, NY: Int. Comm. Nat. Zeolites, (1995), p. 341

[20] A. A. Filippidis, Environmental, industrial and agricultural applications of Hellenic Natural Zeolite, Hellenic Journal of Geosciences, 45(20109, p. 91

[21 A. H. Englert, J. Rubio, Characterization and environmental application of a Chilean natural zeolite, Int. J. Miner. Process, 75(2005), No 1-2, p. 21

[22] K. Saltali, A. Sari, M. Aydin, Removal of ammonium ion from aqueous solution by natural Turkish (Y1ldizeli) zeolite for environmental quality, J. Hazard. Mater, 141(2007) No.1, p. 258

[23] A. Godelitsas, P. Misaelides, A. Filippidis, D. Charistos, I. Anousis, Uranium sorption from aqueous solutions on sodium-form of HEUtype zeolite crystals, J. Radioanal. Nucl. Chem. 208(1996), No. 2, p. 393
[24] P. Misaelides, Application of natural zeolites in environmental remediation: A short review, Microporous Mesoporous Mater. 44(2011), No.1-3, p. 15

[25] R. Leyva-Ramos, J. E. MonsivaisRocha, A. Aragon-Piña, M. S. BerberMendoza, R. M. Guerrero-Coronado, P. Alonso-Davila, J. Mendoza-Barron, Removal of ammonium from aqueous solution by ion exchange on natural and modified chabazite, J. Environ. Manage., 91(2010), p. 2662

[26] D. W. Ming and E. R. Allen, Use of natural zeolites in agronomy, horticulture, and environmental soil remediation, Rev. Mineral. Geochem., 45 (2001), p. 618

[27] C. Colella, Natural zeolites and environment, Stud. Surf. Sci. Catal., 2007, Chapter 27, p. 999

[28] P. Cappelletti, G. Rapisardo, B. de Gennaro, A. Colella, A. Langella, S. F. Graziano, D. L. Bish, M. de Gennaro, Immobilization of $\mathrm{Cs}$ and $\mathrm{Sr}$ in aluminosilicate matrices derived from natural zeolites, J. Nucl. Mater., 414(2011), p. 451

[29] A. Filippidis, G. Papastregios, N. Apostolidis, S. Filippidis, I. Paragios, C. Sikalidis, Purification of urban wastewaters by Hellenic natural zeolite, Bulletin of the Geological Society of Greece, 43(2010), No.5, p. 2597

[30] G. Mertens, R. Snellings, K. Van Balen, B. Bicer-Simsir, P. Verlooy, J. Elsen, Pozzolanic reactions of common natural zeolites with lime and parameters affecting their reactivity, Cem. Concr. Res., 39(2009), No.3, p. 233

[31] M. Doldi, P. Cappelletti, G.Cerri, M. Gennaro, R. Gennaro, A. Langella, Zeolitic tuffs as raw materials for lightweight aggregates., Key Eng. Mater., 2004, No. 264-268, p. 1431

[32] R.de' Gennaro, P. Cappelletti, G. Cerri, M. de' Gennaro, M. Doldi, A. 
Langella, Zeolitic tuffs as raw materials for lightweight aggregates, Appl. Clay Sci., 25(2004), No.1-2, p. 71

[33] V. Lilkov, O. Petrov, V. Petkova, N. Petrova, Y. Tzvetanova, Study of the pozzolanic activity and hydration products of cement pastes with addition of natural zeolites, Clay Miner., 46(2011), p. 241

[34] V. Lilkov, O. Petrov, Y. Tzvetanova, Rheological, porosimetric, and SEM studies of cements with additions of natural zeolites, Clay Miner., 46(2011) p. 225

[35] S. J. Chipera, D. L. Bish, Rehydration kinetics of a natural analcime, Eur. J. Mineral., 22(2010), p. 787

[36] C. Colella, A critical reconsideration of biomedical and veterinary applications of natural zeolites, Clay Miner., 46(2011), No. 2, p. 295

[37] Z. Polat, Integrated approach to whey utilization through natural zeolite adsorption/desorption and fermentation, [Dissertation], The Graduate School of Engineering and Sciences, Izmir, 2009, p. 209

[38] C. Orha, F. Manea, A. Pop, G. Burtica, I. F. Todea, Obtaining and Characterization of Zeolitic Materials with Antibacterial Properties, Rev. Chim., 59(2008), No. 2, p. 173

[39] Yu. I. Tarasevich, I. G. Polyakova, V. E. Polyakov, Microcalorimetric Study of the Interaction between Water and Cation-Substituted Clinoptilolites, Colloid J., 65(2003), No. 4, p. 493

[40] B. Tomazović, T. Ćeranić, G. Sijarić, The properties of the NH,-clinoptilolite, Zeolites, 16(1996) No.4, p. 301

[41] M. Trgo, J.Perić, Interaction of the zeolitic tuff with $\mathrm{Zn}$-containing simulated pollutant solutions, J. Colloid Interface Sci., 260(2003), No. 1, p. 166

[42] P. Misaelides, V.A. Nikashina, A. Godelitsas, P.A. Gembitskii, E.M.
Kats, Sorption of As(V)-anions from aqueous solutions by organo-modified natural zeolitic materials, J. Radioanal. Nucl. Chem. 227(1998), No. 1-2, p. 183

[43] J. Mendoza-Barrón, A. Jacobo-Azuara, R. Leyva-Ramos, M.S. Berber-Mendoza, R. M. Guerrero-Coronado, L. Fuentes-Rubio, J.M. Martínez-Rosales, Adsorption of arsenic (V) from a water solution onto a surfactant-modified zeolite, Adsorption, 17(2011), No. 3, p. 489

[44] L. Ćurković, M. Trgo, M. Rožić, N. V. Medvidović, Kinetics and thermodynamics study of copper ions removal by natural clinoptilolite, Indian J. Chem. Technol., 18(2011), No. 2, p. 137

[45] M. Trgo, J. Perić, N. V. Medvidović, A comparative study of ion exchange kinetics in zinc/lead-modified zeoliteclinoptilolite systems, J. Hazard. Mater., 136(2006), No. 3, p.938

[46] J. A. Simpson, R. S. Bowman, Nonequilibrium sorption and transport of volatile petroleum hydrocarbons in surfactant-modified zeolite, J. Contam. Hydrol., 108(2009), No. 1-2, p. 1

[47] H. Faghihian, R. S. Bowman, Adsorption of chromate by clinoptilolite exchanged with various metal cations, Water Res., 39(2005), No. 6, p. 1099

[48] E. J. Sullivan, R. S. Bowman, I. A. Legiec, Sorption of Arsenic from SoilWashing Leachate by SurfactantModified Zeolite, J. Environ. Qual., 32(2003), No. 6, p. 2387

[49]. R. S. Bowman, Applications of surfactant-modified zeolites to environmental remediation, Microporous Mesoporous Mater., 61(2003), No. 1-3, p. 43

[50] M. Tomašević-Čanović, A. Daković, G. Rottinghaus, S. Matijašević, M. Duričić, Surfactant modified zeolites new efficient adsorbents for myco- 
toxins, Microporous Mesoporous Mater.,61(2003), No. 1-3, p. 173

[51] A. Vujaković, M. Tomaševíć-Čanović, A. Daković, V. Dondur, The adsorption of sulphate, hydrogenchromate and dihydrogenphosphate anions on surfactant-modified clinoptilolite, Appl. Clay Sci. , 17(2000), No. 5-6, p. 265

[52] A. Daković, M. Tomašević-Čanović, G. Rottinghaus, V. Dondur, Z. Mašić, Adsorption of ochratoxin A on octadecyldimethyl benzyl ammonium exchanged-clinoptilolite-heulandite tuff, Colloids Surf. B., 30(2003), No. 1-2, p. 157

[53] T. Stanić, A. Daković, A. Živanović, M. Tomašević-Čanović, V. Dondur, S. Milićević, Adsorption of arsenic (V) by iron (III)-modified natural zeolitic tuf, Environ. Chem. Lett., (2009), p. 161
[54] D. Krajišnik, A. Daković, M. Milojević, A. Malenović, M. Kragović, D. B. Bogdanović, V. Dondur, J. Milić, Properties of diclofenac sodium sorption onto natural zeolite modified with cetylpyridinium chloride, Colloids Surf. B , 83(2011), p. 165

[55] Š. Cerjan Stefanović, N. Logar Zabukovec, K. Margeta, N. Novak Tušar, I. Arčon, K. Maver, J. Kovač, J. Kaučič, Structural investigation of $\mathrm{Zn} 2+$ sorption on clinoptilolite tuff from the Vranjska Banja deposit in Serbia, Microporous Mesoporous Mater., 105(2007), p. 251

[56] M. Šiljeg, S.C. Stefanović, M. Mazaj, N. Tušar, I. Arčon, J. Kovač, K. Margeta, N.Z. Logar, Structure investigation of As(III)- and As(V)-species bound to Fe-modified clinoptilolite tuffs, Microporous Mesoporous Mater. 118(2009), No. 1-3, p. 408 